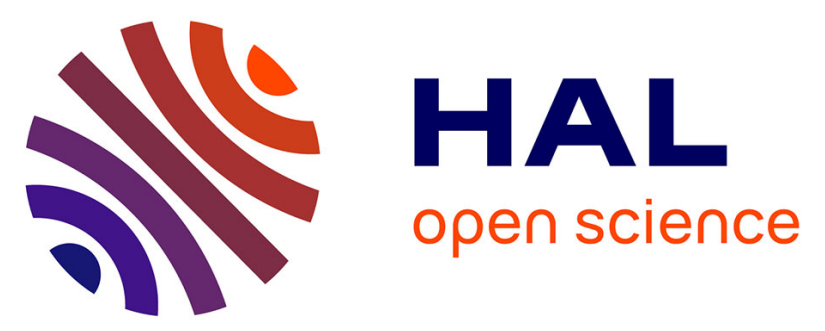

\title{
Expression, protein stability and transcriptional activity of retinoic acid receptors are affected by microtubules interfering agents and - retinoic acid in primary rat hepatocytes
}

Zdeněk Dvořák, Radim Vrzal, Jitka Ulrichová, Dana Macejová, Slavomíra Ondková, Július Brtko

\section{To cite this version:}

Zdeněk Dvořák, Radim Vrzal, Jitka Ulrichová, Dana Macejová, Slavomíra Ondková, et al.. Expression, protein stability and transcriptional activity of retinoic acid receptors are affected by microtubules interfering agents and - retinoic acid in primary rat hepatocytes. Molecular and Cellular Endocrinology, 2007, 267 (1-2), pp.89. 10.1016/j.mce.2007.01.004 . hal-00531908

\author{
HAL Id: hal-00531908 \\ https://hal.science/hal-00531908
}

Submitted on 4 Nov 2010

HAL is a multi-disciplinary open access archive for the deposit and dissemination of scientific research documents, whether they are published or not. The documents may come from teaching and research institutions in France or abroad, or from public or private research centers.
L'archive ouverte pluridisciplinaire HAL, est destinée au dépôt et à la diffusion de documents scientifiques de niveau recherche, publiés ou non, émanant des établissements d'enseignement et de recherche français ou étrangers, des laboratoires publics ou privés. 


\section{Accepted Manuscript}

Title: Expression, protein stability and transcriptional activity of retinoic acid receptors are affected by microtubules interfering agents and all-trans retinoic acid in primary rat hepatocytes

Authors: Zdeněk Dvořák, Radim Vrzal, Jitka Ulrichová, Dana

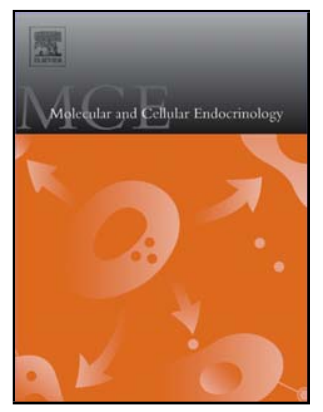

Macejová, Slavomíra Ondková, Július Brtko

PII:

S0303-7207(07)00021-4

DOI:

doi:10.1016/j.mce.2007.01.004

Reference:

MCE 6588

To appear in:

Molecular and Cellular Endocrinology

Received date:

22-8-2006

Revised date:

16-11-2006

Accepted date:

$2-1-2007$

Please cite this article as: Dvořák, Z., Vrzal, R., Ulrichová, J., Macejová, D., Ondková, S., Brtko, J., Expression, protein stability and transcriptional activity of retinoic acid receptors are affected by microtubules interfering agents and all-trans retinoic acid in primary rat hepatocytes, Molecular and Cellular Endocrinology (2007), doi:10.1016/j.mce.2007.01.004

This is a PDF file of an unedited manuscript that has been accepted for publication. As a service to our customers we are providing this early version of the manuscript. The manuscript will undergo copyediting, typesetting, and review of the resulting proof before it is published in its final form. Please note that during the production process errors may be discovered which could affect the content, and all legal disclaimers that apply to the journal pertain. 
Dvořák et al.; Regulation of RAR receptors in rat hepatocytes.

\section{EXPRESSION, PROTEIN STABILITY AND TRANSCRIPTIONAL ACTIVITY OF RETINOIC ACID RECEPTORS ARE AFFECTED BY MICROTUBULES INTERFERING AGENTS AND ALL-TRANS RETINOIC ACID IN PRIMARY RAT HEPATOCYTES}

Zdeněk Dvořák ${ }^{1}$, Radim Vrzal ${ }^{1}$, Jitka Ulrichová ${ }^{1}$, Dana Macejová2 ${ }^{2}$ Slavomíra Ondková2, Július Brtkoº

${ }^{1}$ Institute of Medical Chemistry and Biochemistry, Faculty of Medicine, Palacký University Olomouc, Hněvotínská 3, 77515 Olomouc, Czech Republic

${ }^{2}$ Laboratory of Molecular Endocrinology, Institute of Experimental Endocrinology, Slovak Academy of Sciences, Vlárska 3, Bratislava 83306, Slovak Republic.

Corresponding author: Dr. Zdeněk Dvořák

Institute of Medical Chemistry and Biochemistry

Medical Faculty, Palacký University Olomouc

Hněvotínská 3

77515 OLOMOUC

Czech Republic

Email: moulin@email.cz

Tel.: ++420-58-5632311; Fax.: ++420-58-5632302

Keywords: Retinoic acid receptors; Cellular signaling; Microtubules; Rat hepatocytes 
Dvořák et al.; Regulation of RAR receptors in rat hepatocytes.

\begin{abstract}
Cellular signaling by glucocorticoid receptor and aryl hydrocarbon receptor is restricted by microtubules interfering agents (MIAs). This leads to down-regulation of drug metabolizing enzymes and drug interactions. Here we investigated the effects of all-trans retinoic acid (ATRA) and MIAs, i.e. colchicine, nocodazole and taxol on the regulation of retinoic acid receptor (RAR) genes in primary cultures of rat hepatocytes. ATRA $(1 \mu \mathrm{M})$ down-regulated RAR $\alpha$ and RAR $\gamma$ mRNAs (decrease 23\% and 41\%, respectively) whereas it up-regulated RAR $\beta$ mRNA (4.3 fold induction). All MIAs diminished the expression of RARs in dose-dependent manner; the potency of MIAs increased in order NOC $<$ COL $<$ TAX and the extent of inhibition increased in order RAR $\alpha<\operatorname{RAR} \gamma<\operatorname{RAR} \beta$. The levels of RAR $\alpha$ protein were decreased by both MIAs and ATRA. The effects of ATRA were reversed by proteasome inhibitor MG132, implying ligand-dependent RAR $\alpha$ degradation. In contrast, the effects of MIAs were proteasome-independent and decrease in RAR $\alpha$ protein content was due to RAR $\alpha$ gene down-regulation. We monitored transcriptional activity of RAR $\alpha$. For this purpose, we measured catalytic activity of trans-glutaminase - target gene of RAR $\alpha$. Transglutaminase activity was increased by ATRA ( 1.23 fold increase) and decreased by colchicine (decrease 51\%). Co-treatment with proteasome inhibitor MG132 partly reversed inhibitory effect of colchicine, and it further augmented the increase of trans-glutaminase activity by ATRA. We have also observed decrease of RAR $\alpha$ protein level and inhibition of RARs mRNAs expression in HeLa cells by MIAs. In conclusion, our data indicate that microtubules play the role in regulation of RARs activity and expression. Our data are the first report on the effects of ATRA and MIAs on RARs regulation in quiescent cells.
\end{abstract}


Dvořák et al.; Regulation of RAR receptors in rat hepatocytes.

\section{INTRODUCTION}

Cellular signaling by nuclear receptors, including steroid, thyroid and retinoid receptors, is influenced by variety of endogenous factors as well as exogenous stimuli such as inflammation, infection, stress, drugs, environmental pollutants, UV-light etc. Perturbation of cytoskeleton can be considered as pathophysiological factor affecting the function of several nuclear receptors with consequences in endogenous metabolism as well as in drug metabolism [1]. For instance, microtubules interfering agents (MIAs) colchicine and nocodazole downregulated expression of important biotransformation enzymes in primary human hepatocytes via inhibition of glucocortico id receptor (GR) nuclear import and suppression of its transcriptional activity [1,2]. Recently, drug-drug interaction between administered colchicine and anti-coagulants was attributed to down-regulation of CYP2C9 by microtubule disruption and subsequent diminution of anti-coagulant metabolism [3,4]. Similarly, inhibitory effects of MIAs on aryl hydrocarbon receptor (AhR)-dependent cytochrome P450 CYP1A1 expression were reported [5-8]. Albeit the role of microtubules network in cellular signaling by GR and AhR receptors is ambiguous, there are apparently differences between effects in proliferating and non-proliferating cells [9-11]. Inhibitory effects of MIAs on nuclear receptors in proliferating cells were attributed to the oscillation of the receptors function throughout the cell cycle, implying minimal activities of GR [12-18] and AhR [5-7] in G2/M phase of the cycle. However, down-regulation of AhR and GR dep endent genes was observed in hepatocytes, which are non-proliferating (quiescent) cells. The inhibition of GR function in hepatocytes proceeded probably via activation of c-Jun-N-terminal kinase (JNK) that in turn negatively modulated transcrip tional activity of GR, but the mechanism of AhR inhibition was not elucidated yet [19].

Retinoic acid receptors (RARs) are typical nuclear receptors that are involved in essential endogenous processes and they are often targets in human pharmacotherapy [20]. Retinoids have been studied as chemopreventive agents in clinical trials due to their established role in regulating cell growth, differentiation and apoptosis in preclinical models [21]. Based on the knowledge available, we may anticipate that cellular signaling by RARs could be affected by MIAs. Surprisingly, to date, there is only one report on the possible interactions between MIAs and RARs. It describes synergistic cytotoxicity exhibited by combination treatment with selective retinoid ligands and taxol, but the mechanism was not investigated [22]. Thus, further investigation of the effects of MIAs on cellular signaling by RARs should be carried out because both MIAs (e.g. vincristine, vinblastine, vimentine, taxol, colcemide, colchicine) and retinoids are used in human 
Dvořák et al.; Regulation of RAR receptors in rat hepatocytes.

pharmacotherapy and possible drug interactions may occur. In addition, it is well known that RARs proteins undergo ligand-dependent proteasome-mediated degradation, similarly as other nuclear receptors do. The effects of all-trans retinoic acid (ATRA) on RARs proteins stability were described in numerous cell lines [23-27], however the data from nonproliferating cells are scarce.

The aims of present study were to examine the effects of MIAs (colchicine, nocodazole, taxol) and all-trans retinoic acid (ATRA) on cellular signaling by RARs in primary rat hepatocytes as model no-proliferating cells. We evaluated: i) Expression of RAR $\alpha$, RAR $\beta$ and RAR $\gamma$ mRNAs; ii) Expression and stability of RAR $\alpha$ protein; iii) Transcriptional activity of RARs - monitored as catalytic activity of trans-glutaminase, the target gene of RARs. In parallel, we have performed pilot examination of MIAs and ATRA effects on the expression of RAR receptors in HeLa cells, as the model of proliferating cells.

\section{Materials and methods}

\section{Chemicals}

Williams' medium E, bovine serum, foetal calf serum, penicillin, streptomycin, L-glutamine, sodium pyruvate, dexamethasone, all-trans retinoic acid, proteasome inhibitor MG-132, colchicine, nocodazole, taxol, monoclonal anti- $\beta$-tubulin antibody and Kodak X-Omat AR photographic film were purchased from Sigma Chemicals (St. Louis, MO, USA). Trizol ${ }^{\mathbb{R}}$ Reagents, was purchased from GibcoBRL Life Technologies (Cergy Pontoise, France). Complete ${ }^{\mathrm{TM}}$ protease inhibitor cock tail tablets was purchased from Roche Diagnostics $\mathrm{GmbH}$ (Mannheim, Germany). Secondary horseradish peroxidase conjugated antibody, and Western Blotting Luminol Reagent were purchased from Santa Cruz Biotechnology (Santa Cruz, CA, USA). Alexa Fluor 596-conjugated anti-mouse IgG was purchased from Molecular Probes (Eugene, OR, USA). All other chemicals were of the highest grade commercially av ailable.

\section{Rat hepatocytes cultures}

Primary rat hepatocytes were isolated by two-step collagenase perfusion according to a published protocol [28]. Following isolation, the cells were plated on collagen-coated culture dishes using cell density $2 \times 10^{5}$ cells $/ \mathrm{cm}^{2}$. Williams' medium E supplemented with $2 \mathrm{mM} \mathrm{L-}$ glutamine, $10 \mu \mathrm{M}$ streptomycin, $100 \mathrm{U} / \mathrm{mL}$ penicillin, $350 \mathrm{nM}$ insulin, and $1 \mu \mathrm{M}$ dexamethasone, was used for culture mainten ance. The medium was enriched for plating with $5 \%$ bovine serum $(\mathrm{FCS})(\mathrm{v} / \mathrm{v})$. After $4 \mathrm{~h}$, culture medium was replaced by a serum-free one 
Dvořák et al.; Regulation of RAR receptors in rat hepatocytes.

and the cells were ready for the treatments. Cultures were maintained at $37^{\circ} \mathrm{C}$ in $5 \% \mathrm{CO}_{2}$ (air: $\mathrm{CO}_{2}, 95: 5$ ) humidified incubator.

\section{HeLa cell cultures}

Human Negroid cervix epitheloid carcinoma cells HeLa (ECACC No. 93021013) were cultured in Dulbecco`s modified Eagle`s medium (DMEM) supplemented with 10\% FCS, 100 $\mathrm{U} / \mathrm{mL}$ streptomycin, $100 \mu \mathrm{g} / \mathrm{mL}$ penicillin, $4 \mathrm{mM} \mathrm{L}$-glutamine, and non-essential amino acids. Cultures were maintained at $37^{\circ} \mathrm{C}$ in $5 \% \mathrm{CO}_{2}\left(\right.$ air: $\left.\mathrm{CO}_{2}, 95: 5\right)$ humidified incubator. For the treatments, the cells were plated on Petri dishes (100 mm I.D.) in a density of $2 \times 10^{6}$ cells/dish. Cells were allowed to grow up to $70-80 \%$ of confluence. Following exchange for a serum-free medium, the culture was stabilized for an additional $4-6 \mathrm{~h}$ prior to the treatments.

\section{mRNA analyses}

Rat hepatocytes were plated on collagen-coated Petri dishes (100 mm I.D.) in a density of $1 \mathrm{x}$ $10^{7}$ cells/well using culture media enriched with bovine serum $(5 \% \mathrm{v} / \mathrm{v})$. After $4 \mathrm{~h}$, culture medium was replaced by a serum-free one. Thereafter, the cells were treated $24 \mathrm{~h}$ with alltrans retinoic acid (ATRA; $1 \mu \mathrm{M}$ ), colchicine (COL; $0.1 \mu \mathrm{M}$ and $1 \mu \mathrm{M}$ ), nocodazole (NOC; 1 $\mu \mathrm{M}, 10 \mu \mathrm{M}$ and $40 \mu \mathrm{M}$ ), taxol (TAX; $1 \mu \mathrm{M}, 10 \mu \mathrm{M}$ and $40 \mu \mathrm{M})$ and/or with DMSO as vehicle for control. Total RNA was isolated using Trizol reagent according to the manufacturer's instructions. Concentration of RNA was quantified by spectrometry at $260 \mathrm{~nm}$ and purity was assessed from the ratio of absorbances $A_{260 n m} / A_{280 n m}$. Reverse transcription (RT) was performed with $2 \mu \mathrm{g}$ of to tal RNA and the Ready-to-Go You-Prime First-Strand Beads (Amersham Pharmacia Biotech,Inc., USA) according to the manufacturer's protocol. PCR was performed in a $25 \mu 1$ total volume consisting of $4 \mu 1 \mathrm{RT}$ mixture, $2.5 \mu 1$ of 10x PCR buffer, $0.75 \mu \mathrm{l}$ of $50 \mathrm{mM} \mathrm{MgCl} 2,0.5 \mu 110 \mathrm{mM} \mathrm{dNTP,} 25$ pmol of each specific gene primer set and 0.6 U of DyNAzyme II DNA polymerase (Finnzymes OY, Finland) in buffer provided by the manufacturer. After treatment of samples at $94^{\circ} \mathrm{C}$ for $3 \mathrm{~min}$ to inactivate reverse transcriptase, PCR consisted of 35 cycles of denaturing $\left(95^{\circ} \mathrm{C}, 45 \mathrm{sec}\right)$, annealing $\left(57^{\circ} \mathrm{C}, 30\right.$ $\mathrm{sec})$, extension $\left(72^{\circ} \mathrm{C}, 90 \mathrm{sec}\right)$, and a final extension at $72^{\circ} \mathrm{C}$ for $10 \mathrm{~min}$. The oligonucleotide sequences of primers used in PCR are rat RAR $\alpha$ : sense 5'-CAGATGCACAACGCTGGC-3', antisense 5'-CCGACTGTCCGCTTAGAG-3'; rat RAR $\beta$ : sense 5'ATGCTGGCTTCGGTCCTC-3', antisense 5'-CTGCAGCAGTGGTGACTG-3'; rat RAR $\gamma$ : 
Dvořák et al.; Regulation of RAR receptors in rat hepatocytes.

sense 5'-GTGGAGACCGAATGGACC-3', antisense 5'-GACAGGGATGAACACAGG-3' and GAPDH: sense 5'-TGAACGGGAAGCTCACTGG-3', antis ense 5'-

TCCACCACCCTGTTGCTGTA-3'. These conditions were proven to be in the log phase for each amplified sequence by us or were already described elsewhere [29]. The PCR products were separated on $2 \%$ agarose gel and stained with ethidium bromide. The band intensities were measured using the STS 6220I Documentation System (Ultralum, USA) and normalized to the band intensity of PCR product corresponding to the house keeping gene GAPDH. Analogical experiments were performed in HeLa cells. PCR was performed in a $25 \mu 1$ total volume consisting of $4 \mu \mathrm{l}$ (RAR $\alpha$ and $\gamma, \mathrm{GAPDH})$ and $8 \mu \mathrm{l}$ (RAR $\beta$ ) RT mixture, $2.5 \mu 1$ of 10x PCR buffer, $0.75 \mu 1$ of $50 \mathrm{mM} \mathrm{MgCl}_{2}, 0.5 \mu 110 \mathrm{mM} \mathrm{dNTP,} 25$ pmol of each specific gene primer set and 0.6 U of DyNAzyme II DNA polymerase (Finnzymes OY, Fin land) in buffer provided by the manufacturer. After treatment of samples at $94^{\circ} \mathrm{C}$ for $3 \mathrm{~min}$ to inactivate reverse transcriptase, PCR consisted of 35 cycles of denaturing $\left(95^{\circ} \mathrm{C}, 1 \mathrm{~min}\right)$, ann ealing $\left(60^{\circ} \mathrm{C}, 1 \mathrm{~min}-\mathrm{RAR} \alpha\right.$ and $\left.\gamma, \mathrm{GAPDH}\right)$ and $\left(62^{\circ} \mathrm{C}, 1 \mathrm{~min}-\mathrm{RAR} \beta\right)$, extension $\left(72^{\circ} \mathrm{C}, 1 \mathrm{~min}\right)$, and a final extension at $72^{\circ} \mathrm{C}$ for $10 \mathrm{~min}$. The oligonucleotide sequences of primers used in PCR are: human RAR $\alpha$ sense 5'-ACCCCCTCTACCCCGCATCTACAAG-3', antisense 5'CATGCCCACTTCAAAGCACTTCTGC-3'; human RAR $\beta$ sense 5 'ATTCCAGTGCTGACCATCGAGTCC-3', antisense 5'CCTGTTTCTGTGTCATCCATTTCC-3'; human RAR $\gamma$ sense 5'TACCACTATGGGGTCAGC-3', antisense 5'-CCGGTCATTTCGCACAGCT-3' [30].

\section{Protein analyses}

Rat hepatocytes were seeded on 6-well dishes in a density of $2 \times 10^{6}$ cells/well using culture media enriched with bovine serum $(5 \% \mathrm{v} / \mathrm{v})$. After $4 \mathrm{~h}$, culture medium was replaced by a serum-free one. Thereafter, the cells were treated $24 \mathrm{~h}$ with all-trans retinoic acid (ATRA; 1 $\mu \mathrm{M})$, proteasome inhibitor MG-132 $(1 \mu \mathrm{M})$, colchicine (COL; $0.1 \mu \mathrm{M}$ and $1 \mu \mathrm{M})$, nocodazole (NOC; $1 \mu \mathrm{M}, 10 \mu \mathrm{M}$ and $40 \mu \mathrm{M}$ ), taxol (TAX; $1 \mu \mathrm{M}, 10 \mu \mathrm{M}$ and $40 \mu \mathrm{M}$ ) and/or with DMSO as vehicle for control. Total protein extracts were prepared as follows: Cells were washed twice with $1 \mathrm{~mL}$ of ice-cold PBS and scraped into $1 \mathrm{~mL}$ of PBS. The suspension was centrifuged $\left(1500 \mathrm{~g} / 5 \mathrm{~min} / 4^{\circ} \mathrm{C}\right)$ and the pellet was vigorously re-suspended in $150 \mu \mathrm{L}$ of icecold lysis buffer (10 mM Hepes pH 7.9; $10 \mathrm{mM} \mathrm{KCl} ; 1.5 \mathrm{mM} \mathrm{MgCl} 2 ; 0.5 \mathrm{mM} \mathrm{DTT} ; 0.1 \% \mathrm{v} / \mathrm{v}$ NP-40; anti-protease cocktail, $0.2 \% \mathrm{w} / \mathrm{v}$ sodium dodecylsulfate). The mixture was incubated 
Dvořák et al.; Regulation of RAR receptors in rat hepatocytes.

for $20 \mathrm{~min}$ on ice and then centrifuged $\left(12000 \mathrm{~g} / 10 \mathrm{~min} / 4^{\circ} \mathrm{C}\right)$. Supernatant was collected and the protein content in extracts was determined by the biscinchoninic acid method.

The extracts were analyzed on SDS-PAGE gels (7.5\%) according to the general procedure [31]. Protein transfer onto nitrocellulose membrane was carried out as described [32]. The membrane was stained with Ponceau S red dye for control of transfer and then saturated with $8 \%$ non-fat dried milk overnight. Blots were probed with primary antibodies against: retinoic acid receptor alpha (sc-551; RAR $\alpha(\mathrm{C}-20)$ rabbit polyclonal; dilution 1/1000) and $\alpha$-actin (sc1616; Actin (I-19) goat polyclonal; dilution 1/1000); both purchased from Santa Cruz Biotechnology, Inc. (Santa Cruz, USA). Chemiluminescence detection using horseradish peroxidase conjugated secondary antibodies and an Amersham ECL kit was performed. Analogical experiments were performed in HeLa cells.

\section{Histochemical detection of microtubules disruption}

Rat hepatocytes were plated on collagen-coated glass slides at density $5 \times 10^{5}$ cells $/ \mathrm{cm}^{2}$. Cells were treated for $24 \mathrm{~h}$ with colchicine $(\mathrm{COL} ; 0.1 \mu \mathrm{M}, 1 \mu \mathrm{M})$, nocodazole (NOC; $1 \mu \mathrm{M}, 10 \mu \mathrm{M}$, $40 \mu \mathrm{M}$ ), taxol (TAX; $1 \mu \mathrm{M}, 10 \mu \mathrm{M}, 40 \mu \mathrm{M}$ ); and DMSO as vehicle for control. Cells were then washed twice with ice-cold PBS, fixed with methanol, and washed twice with PBS. After blocking for $60 \mathrm{~min}$ in $5 \%(\mathrm{w} / \mathrm{v})$ bovine serum albumin, cells were incubated with monoclonal anti- $\beta$-tubulin antibody for $60 \mathrm{~min}$. Secondary antibody used was Alexa Fluor 596-conjugated anti-mouse IgG. Microscopy (400 x magnification) was performed on Olympus microscopes and digital images of all cultures were taken and stored as JPG files.

\section{Cytotoxicity assays}

Rat hepatocytes were seeded on 96-well collagen-coated dishes using culture media enriched with bovine serum $(5 \% \mathrm{v} / \mathrm{v})$. Following $4 \mathrm{~h}$ of stabilization, the cells were treated for $24 \mathrm{~h}$ with tested compounds. In parallel, cultures were treated with DMSO (vehicle) and 1\% v/v Triton X-100 to assess the minimal and maximal cell damage, respectively. MTT assay was measured spectrophotometrically at $540 \mathrm{~nm}$ (TECAN, Schoeller Instruments s.r.o.). The data were expressed as $\%$ of viability, when $100 \%$ and $0 \%$ represent the treatments with DMSO and Triton X-100, respectively. 
Dvořák et al.; Regulation of RAR receptors in rat hepatocytes.

\section{Tissue trans-glutaminase activity assay}

Rat hepatocytes were plated on collagen-coated Petri dishes (100 mm I.D.) in a density of $1 \mathrm{x}$ $10^{7}$ cells/well using culture media enriched with foetal calf serum $(5 \% \mathrm{v} / \mathrm{v})$. After $4 \mathrm{~h}$, culture medium was replaced by a serum-free one. Thereafter, the cells were treated $24 \mathrm{~h}$ with alltrans retinoic acid (ATRA; $1 \mu \mathrm{M})$, colchicine $(\mathrm{COL} ; 1 \mu \mathrm{M})$ and with DMSO as vehicle for control. Cells were washed twice with $1 \mathrm{~mL}$ of ice-cold PBS and scraped in to $1 \mathrm{~mL}$ of PBS. The suspension was cen trifuged $\left(1500 \mathrm{~g} / 5 \mathrm{~min} / 4^{\circ} \mathrm{C}\right)$ and resulting pellet was stored at $-80^{\circ} \mathrm{C}$. Tissue trans-glutaminase activity assay was measured by detecting the incorporation of $\left[{ }^{3} \mathrm{H}\right]$ putrescine into $\mathrm{N}, \mathrm{N}^{\prime}$-dimethylcaseine [33]. One of the functions of tissue transglutaminase is to form a protein polymer by epsilon(gamma-glutamyl)lysine and, specifically gammaglutamylpolyamine cross-links. A slight modification of the method commonly used for tissue transglutaminase activity in liver tissue [34] enabled us to adapt that assay in which the protein concentration either in PBMC or cell culture samples was reduced six times [35].

\section{Results}

Effects of microtubule interfering agents on viability and microtubular network of primary rat hepatocytes

Prior to the principal experiments, we have examined the effects of MIAs on the viability and microtubular network integrity in primary rat hepatocytes. Viability of the cells was assessed as MTT test (Figure 1). The effects of MIAs on microtubules network were monitored by immune-histochemical detection of $\beta$-tubulin (Figure 2). Based on these results, we used following concentrations of MIAs in ongoing experiments: colchicine (COL; $0.1 \mu \mathrm{M}, 1 \mu \mathrm{M})$, nocodazole (NOC; $1 \mu \mathrm{M}, 10 \mu \mathrm{M}, 40 \mu \mathrm{M}$ ), taxol (TAX; $1 \mu \mathrm{M}, 10 \mu \mathrm{M}, 40 \mu \mathrm{M}$ ). The effects of MIAs in HeLa cells we described elsewhere [10].

Effects of microtubule interfering agents and ATRA on the expression of retinoic acid receptors $m R N A s$

In first series of experiments, we have examined the effects of all-trans retinoic acid (ATRA; $1 \mu \mathrm{M}$ ) and MIAs, i.e. colchicine (COL; $0.1 \mu \mathrm{M}$ and $1 \mu \mathrm{M}$ ), nocodazole (NOC; $1 \mu \mathrm{M}, 10 \mu \mathrm{M}$ and $40 \mu \mathrm{M}$ ), taxol (TAX; $1 \mu \mathrm{M}, 10 \mu \mathrm{M}$ and $40 \mu \mathrm{M}$ ) on the expression of retinoic acid receptors RAR $\alpha, R A R \beta$ and RAR $\gamma$ mRNAs. Primary cultures of rat hepatocytes were treated $24 \mathrm{~h}$ with tested compounds, total RNA was isolated and the levels of RAR $\alpha$, RAR $\beta$, RAR $\gamma$ and GAPDH mRNAs were determined by RT-PCR. ATRA selectively modulated the 
Dvořák et al.; Regulation of RAR receptors in rat hepatocytes.

expression of RAR genes (Figure 3a); it down-regulated RAR $\alpha$ and RAR $\gamma$ mRNAs (decrease $23 \%$ and $41 \%$, respectively) whereas it up-regulated RAR $\beta$ mRNA (4.3 fold induction). All tested MIAs inhibited the expression of RARs in dose-dependent manner. The potency of tested MIAs increased in order NOC $<\mathrm{COL}<\mathrm{TAX}$ and the extent of inhibition increased in order $\operatorname{RAR} \alpha<\operatorname{RAR} \gamma<\operatorname{RAR} \beta$ (Figure 1).

In parallel, we have examined the effects of MIAs and ATRA on the expression of RAR $\alpha$, RAR $\beta$ and RAR $\gamma$ mRNAs in HeLa cell line, as the model of proliferating cells. Cultures were treated with colchicine (COL; $0.1 \mu \mathrm{M}$ and $1 \mu \mathrm{M}$ ), nocodazole (NOC; $1 \mu \mathrm{M}$ and $10 \mu \mathrm{M}$ ), taxol (TAX; $1 \mu \mathrm{M}$ and $10 \mu \mathrm{M}$ ), all-trans retinoic acid (ATRA; $1 \mu \mathrm{M}$ ) and/or with DMSO as vehicle for control. ATRA increased the levels of all RARs mRNA by factors 1.15, 7.4 and 1.14 for RAR $\alpha, \operatorname{RAR} \beta$ and RAR $\gamma$, respectively (Figure $3 b$ ). Induction of RAR $\beta$ by ATRA was reported also elsewhere [36]. The effects of MIAs on the expression of RARs mRNAs were less pronounced than in rat hepatocytes. The level of RAR $\beta$ mRNA was not altered by MIAs. The potency of MIAs to down-regulate RAR $\alpha$ and RAR $\gamma$ increased in order NOC $<$ COL $<$ TAX; i.e. the same as in hepatocytes (Figure 3b). Note: we did not use NOC and TAX in 40 $\mu \mathrm{M}$ concentration due to high toxicity in HeLa cells.

\section{Effects of microtubule interfering agents and ATRA on the level of RAR $\alpha$ protein}

While the analyses of RARs mRNAs reveal about the effects of tested substances on gene expression of the receptors, the analyses of the protein content comprise additional information on the stability/degradation of the protein products - receptors. Rat hepatocytes were treated $24 \mathrm{~h}$ with colchicine (COL; $0.1 \mu \mathrm{M}$ and $1 \mu \mathrm{M}$ ), nocodazole (NOC; $1 \mu \mathrm{M}, 10 \mu \mathrm{M}$ and $40 \mu \mathrm{M}$ ), taxol (TAX; $1 \mu \mathrm{M}, 10 \mu \mathrm{M}$ and $40 \mu \mathrm{M}$ ), all-trans retinoic acid (ATRA; $1 \mu \mathrm{M}$ ) and/or with DMSO as vehicle for control. Total protein extracts were isolated and subjected to western blot analyses. For protein detection, we have limited our attention to RAR $\alpha$ receptor. ATRA and MIAs decreased the levels of RAR $\alpha$ protein, similarly as they did at the level of mRNA (Figure 4a).

In parallel, we have examined the effects of MIAs and ATRA on the level of RAR $\alpha$ protein in HeLa cells. Cultures were treated $24 \mathrm{~h}$ with colchicine (COL; $0.1 \mu \mathrm{M}$ and $1 \mu \mathrm{M}$ ), nocodazole (NOC; $1 \mu \mathrm{M}$ and $10 \mu \mathrm{M}$ ), taxol (TAX; $1 \mu \mathrm{M}$ and $10 \mu \mathrm{M}$ ), all-trans retinoic acid (ATRA; 1 $\mu \mathrm{M})$ and/or with DMSO as vehicle for control. All tested MIAs and ATRA decreased the 
Dvořák et al.; Regulation of RAR receptors in rat hepatocytes.

level of RAR $\alpha$ protein (Figure 4b). The effects of MIAs were more pronounced in HeLa cells as compared to those in rat hepatocytes.

\section{Effects of colchicine and ATRA on RAR-dependent catalytic activity of trans-glutaminase}

The expression of trans-glutaminase (t-GLUT) is under transcriptional control of RAR $\alpha$. Hence, the alteration in t-GLUT catalytic activity reflects the changes in the number and transcriptional activity of RAR $\alpha$. It gives additional information to the analyses at the level of protein and mRNA, and regarding in vivo or clinical situation, it is the most relevant parameter in the cascade mRNA - protein - activity. Rat hepatocytes were treated $24 \mathrm{~h}$ with colchicine (COL; $1 \mu \mathrm{M})$, all-trans retinoic acid (ATRA; $1 \mu \mathrm{M}$ ) and/or with DMSO as vehicle for control. ATRA, a ligand of RAR $\alpha$, caused an increase in t-GLUT activity by factor 1.23. In contrast, colchicine diminished t-GLUT activity down to $49 \%$ of the activity of control cells (Figure 5).

Effects of proteasome inhibitor MG-132 on colchicine- and ATRA-mediated decrease of $R A R \alpha$ protein and transcriptional activity

Finally, we have investigated the involvement of proteasome in MIAs- and ATRA-elicited alterations in RAR $\alpha$ protein and transcriptional activity. Rat hepatocytes were treated $24 \mathrm{~h}$ with colchicine (COL; $1 \mu \mathrm{M})$, all-trans retinoic acid (ATRA; $1 \mu \mathrm{M})$ and/or with DMSO in the presence or absence of proteasome inhibitor (MG-132; $1 \mu \mathrm{M})$. The levels of RAR $\alpha$ protein and catalytic activity of t-GLUT were determined. The decrease of RAR $\alpha$ protein by ATRA was reversed by MG132, implying ligand-dependent RAR $\alpha$ degradation. In contrast, the effects of MIAs were proteasome-independent and decrease in RAR $\alpha$ protein content was rather due to RAR $\alpha$ gene down-regulation (Figure 6a). MG-132 had no significant effect on basal t-GLUT activity. Co-treatment with MG-132 partly reversed inhibitory effect of colchicine, and it further augmented the increase of t-GLUT activity by ATRA (Figure 6b).

\section{Discussion}

Retinoids have been studied as chemopreventive agents in clinical trials due to their established role in regulating cell growth, differentiation and apoptosis in preclinical models [21]. In this work we describe differential effects of MIAs and ATRA on the regulation of RAR genes in primary rat hepatocytes. In particular, we show that: (i) ATRA down-regulates RAR $\alpha$ and RAR $\gamma$ mRNAs and up-regulates RAR $\beta$ mRNA. MIAs 
Dvořák et al.; Regulation of RAR receptors in rat hepatocytes.

down-regu late RAR $\alpha$, RAR $\beta$ and RAR $\gamma$ mRNAs; (ii) ATRA decreases RAR $\alpha$ protein content by proteasome-dependent degradation. MIAs decrease RAR $\alpha$ protein in proteasomeindepend ent manner; (iii) Transcriptional activity of RAR $\alpha$ (monitored as catalytic activity of t-GLUT) was increased by ATRA and inhibited by colchicine.

The data obtained have two aspects. Mechanistic aspect: The role of microtubules in cellular signaling by steroids and their cognate nuclear receptors is still unresolved issue. We have previously reported the inhibition of transcriptional activity of GR $[1,19]$ and AhR $[8,9]$ by MIAs in human and rat hepatocytes, respectively. Both receptors under investigation, i.e. GR and AhR undergo cytosol to nucleus shuttling. The mechanism of MIAs inhibitory activity against these two receptors comprised at least partly restriction of nuclear import of GR and AhR. Assuming the involvement of microtubules in cellular signaling by these receptors, we should consider at least three mechanisms: (i) microtubules serve as supporting rails in cytosol to nucleus shuttling of the receptors or the factors in charge; (ii) microtubules associated proteins play certain role in the process; (iii) GTPase activity of microtubules is involved in the process. Hence, focusing on exclusively nuclear receptor ( such as RAR $\alpha$ ), which does not require nuclear translocation, we can exclude option "(i)". Primordial question is: Are the effects of MIAs direct or mediated via another receptor/transcriptional factor? While the expression of RXRs in human hepatocytes [37] and rat hepatocytes [38,39] is under transcriptional control of GR, there is lack of information on the transcriptional factors/receptors controlling the expression of RARs. It was reported that dexamethasone (DEX) enhanced RAR $\beta$ mRNA inducibility by ATRA in rat hepatocytes. This increase was inhibited by cycloh eximide whereas the in crease produced by ATRA treatment alone was not affected. These results indicate that DEX also enhances ATRA-dependent transcriptional activation in cultured hepatocytes by inducing RXR $\alpha$. Since MIAs restrict cellular signaling by GR, the inhibitory effects of MIAs on the expression of RARs could be explained by the involvement of GR in transcriptional control of RARs. Different inhibitory potency of MIAs against RARs ( RAR $\alpha<$ RAR $\gamma<$ RAR $\beta$ ) would then be probably due to different contribution of GR in the process of the expression of individual RARs (different number of GRE in RARs promoters). Indeed, we have observed analogical effects on GR-controlled gene expression in human hepato cytes. The inhibitory potency of colchicine and nocodazole on gene expression increased in order $\mathrm{PXR}<\mathrm{CAR}<\mathrm{TAT}$; note: TAT being exclusively GR-regulated gene [1].

Clinical a spect: MI As are clinically u sed as antic ancer drugs (vincristine, vinblastine, taxol) or in the treatment of gout or familial Mediterranean fever (colchicine). We described 
Dvořák et al.; Regulation of RAR receptors in rat hepatocytes.

recently that MIAs restrict cellular signaling by GR in primary human hepato cytes. It resulted in down-regulation of PXR and CAR receptors and P450 enzymes with possible consequences in drug metabolism [1]. For instance, the co-administration of COL and coumarine-based anti-coagulants constitutes a precarious situation because th is type of drugs is metabolized by CYP enzymes, in particular CYP3A4 and CYP2C8. Recent reports attributed the drug-drug interaction to down-regulation of CYP2C9 by microtubule disruption and subsequent retardation of anti-coagu lant metabolism [3,4]. Similarly, attention should be paid when using drugs acting via RARs together with MIAs. For instance, synergistic cytotoxicity exhibited by combination treatment with selective retinoid ligands and taxol was reported [22].

Finally, the data presented in this paper are the first report on the effects of MIAs on the expression and activity of RARs. Future research should focus on the role of GR in regulation of RARs. Since GR transcriptionally regulates also RXRs and thyroid receptor, the effects of MIAs on these receptors should be examined as well.

\section{ACKNOWLEDGEMENTS}

This research was supported by grant MSM 6198959216 from the Ministry of Education, Youth and Sports of the Czech Republic, by grant GACR 303/04/P074 from the Grant Agency of the Czech Republic, and grant VEGA No. 2/5017/5.

List of non-standard abbreviations: AhR, aryl hydrocarbon receptor; ATRA, all-trans retinoic acid; CAR, constitutive androstane receptor; COL, colchicine; DEX, dexamethasone; GR, glucocorticoid receptor; HeLa, human cervix carcinoma epithelial cell line; JNK, c-Jun$\mathrm{N}$-terminal kinase; MG-132, proteaso me inhibitor; MIAs, microtubules interfering agents; NOC, nocodazole; $\mathrm{PXR}$, pregnane $\mathrm{X}$ receptor; $\mathrm{RAR}$, retino ic acid receptor; $\mathrm{RXR}$, retinoin $\mathrm{X}$ receptor; TAX, taxol 
Dvořák et al.; Regulation of RAR receptors in rat hepatocytes.

\section{Figure legends}

Figure 1. Effects of MIAs on viability of primary rat hepatocytes. Cells were treated for $24 \mathrm{~h}$ with colchicine $(\mathrm{COL} ; 0.1 \mu \mathrm{M}, 1 \mu \mathrm{M})$, nocodazole (NOC; $1 \mu \mathrm{M}, 10 \mu \mathrm{M}, 40 \mu \mathrm{M})$, taxol (TAX; $1 \mu \mathrm{M}, 10 \mu \mathrm{M}, 40 \mu \mathrm{M}$ ); and DMSO as vehicle for control. MTT assay was measured as the indicator viability. Cells treated with DMSO represented $100 \%$ metabolic activity in the MTT assay. Bar plots represent means \pm SD from three ind ependent experiments. $*=$ the value is sign ificantly different from that of DMSO-treated cells at $\mathrm{p}<0.05$.

Figure 2. Effects of MIAs on microtubules in tegrity in primary rat hepatocytes. Cells were treated for $24 \mathrm{~h}$ with colchicine (COL; $0.1 \mu \mathrm{M}, 1 \mu \mathrm{M}$ ), nocodazole (NOC; $1 \mu \mathrm{M}, 10 \mu \mathrm{M}$, $40 \mu \mathrm{M}$ ), taxol (TAX; $1 \mu \mathrm{M}, 10 \mu \mathrm{M}, 40 \mu \mathrm{M})$; and DMSO as vehicle for control. Microtubules visualization was performed with monoclonal anti- $\beta$-tubulin antibody followed by Alexa Fluor 596 conjugated anti-mouse IgG. Microscopy (400 x magnification) was performed on Olympus microscopes.

Figure 3. Effects of microtubule interfering agents and ATRA on the expression of retinoic acid receptors mRNAs. Panel A: Primary rat hepatocytes were treated $24 \mathrm{~h}$ with all-trans retinoic acid (ATRA; $1 \mu \mathrm{M}$ ), colchicine (COL; $0.1 \mu \mathrm{M}$ and $1 \mu \mathrm{M}$ ), nocodazole (NOC; $1 \mu \mathrm{M}, 10 \mu \mathrm{M}$ and $40 \mu \mathrm{M}$ ), taxol (TAX; $1 \mu \mathrm{M}, 10 \mu \mathrm{M}$ and $40 \mu \mathrm{M}$ ) and/or with DMSO as vehicle for control. Panel B: Cultures were treated with colchicine (COL; 0.1 $\mu \mathrm{M}$ and 1 $\mu \mathrm{M}$ ), nocodazole (NOC; $1 \mu \mathrm{M}$ and $10 \mu \mathrm{M}$ ), taxol (TAX; $1 \mu \mathrm{M}$ and $10 \mu \mathrm{M}$ ), all-trans retinoic acid (ATRA; $1 \mu \mathrm{M}$ ) and/or with DMSO as vehicle for control. Total RNA was isolated and the levels of RAR $\alpha$, RAR $\beta$, RAR $\gamma$ and GAPDH mRNAs were determined by RT-PCR. The data were normalized per GAPDH content in the respective samples. Bar graphs represent means $\pm \mathrm{SD}$ of three independent experiments. $*=$ the value significantly different from the control value (DMSO) at $\mathrm{p}<0.05$.

Figure 4. Effects of microtubule interfering agents and ATRA on the level of RAR $\alpha$ prote in. Shown are representative Western blots of RAR $\alpha$. Panel A: Rat hepatocytes were treated $24 \mathrm{~h}$ with colchicine (COL; $0.1 \mu \mathrm{M}$ and $1 \mu \mathrm{M}$ ), nocodazole (NOC; $1 \mu \mathrm{M}, 10 \mu \mathrm{M}$ and 
Dvořák et al.; Regulation of RAR receptors in rat hepatocytes.

$40 \mu \mathrm{M}$ ), taxol (TAX; $1 \mu \mathrm{M}, 10 \mu \mathrm{M}$ and $40 \mu \mathrm{M}$ ), all-trans retinoic acid (ATRA; $1 \mu \mathrm{M}$ ) and/or with DMSO as vehicle for control. Panel B: HeLa cells were treated $24 \mathrm{~h}$ with colchicine (COL; $0.1 \mu \mathrm{M}$ and $1 \mu \mathrm{M}$ ), nocodazole (NOC; $1 \mu \mathrm{M}$ and $10 \mu \mathrm{M}$ ), taxol (TAX; $1 \mu \mathrm{M}$ and 10 $\mu \mathrm{M})$, all-trans retino ic acid (ATRA; $1 \mu \mathrm{M})$ and/or with DMSO as vehicle for control. Total protein extracts were isolated and after western blot analysis the membrane was probed with anti RAR $\alpha$ and anti actin antibodies. A similar profile was obtained from three independent experiments.

Figure 5. Effects of colchicine and ATRA on catalytic activity of trans-glutaminase. Rat hepatocytes were treated $24 \mathrm{~h}$ with colchicine $(\mathrm{COL} ; 1 \mu \mathrm{M})$, all-trans retinoic acid (ATRA; 1 $\mu \mathrm{M})$ and/or with DMSO as vehicle for control. Catalytic activity of t-GLUT was measured as described in Materials and Methods section. Bar graphs represent mean \pm SD of four independent experiments. ${ }^{*}=$ the value significantly different from the control value (DMSO) at $\mathrm{p}<0.05$.

Figure 6. Effects of proteasome inhibitor MG-132 on RAR $\alpha$ protein content and transcriptional activity. Rat hepatocytes were treated $24 \mathrm{~h}$ with colchicine (COL; $1 \mu \mathrm{M})$, alltrans retinoic acid (ATRA; $1 \mu \mathrm{M}$ ) and/or with DMSO in the presence or absence of proteasome inhibitor (MG-132;1 1 M). Panel A: Total protein extracts were isolated and after western blot analysis the membrane was probed with anti RAR $\alpha$ and anti actin antibodies. A similar profile was obtained from two independent experiments. Panel B: Catalytic activity of t-GLUT was measured as described in Materials and Methods section. Bar graphs represent means \pm SD of three independent experiments. $*=$ the value is significantly different from the control value $(\mathrm{DMSO})$ at $\mathrm{p}<0.05$. \# = the value is significantly different from the treatments in the absence of MG132 at $\mathrm{p}<0.05$. 
Dvořák et al.; Regulation of RAR receptors in rat hepatocytes.

\section{References}

[1] Pascussi, J.M., Dvorak, Z., Gerbal-Chaloin, S., Assenat, E., Maurel, P. and Vilarem, M.J. (2003) Pathophysiological factors affecting CAR gene expression. Drug Metab Rev 35, 255-68.

[2] Dvorak, Z., Ulrichova, J., Pichard-Garcia, L., Modriansky, M. and Maurel, P. (2002) Comparative effect of colchicine and colchiceine on cytotoxicity and CYP gene expression in primary human hepatocytes. Toxicol In Vitro 16, 219-27.

[3] Gras-Champel, V., Ohlmann, P., Polard, E., Wiesel, M.L., Imbs, J.L. and Andrejak, M. (2005) Can colchicine potentiate the anticoagulant effect of fluindione? Eur J Clin Pharmacol 61, 555-6.

[4] Rojas, J.C., Aguilar, B., Rodriguez-Maldonado, E. and Collados, M.T. (2005) Pharmacogenetics of oral an ticoagulants. Blood Coagul Fibrinolys is 16, 389-98.

[5] Bonzo, J.A., Chen, S., Galijatovic, A. and Tukey, R.H. (2005) Arsenite Inhibition of CYP1A1 Induction by 2,3,7,8-Tetrachlorodibenzo-p-dioxin Is Independent of Cell Cycle Arrest. Mol Pharmacol 67, 1247-56.

[6] Santini, R.P., Myrand, S., Elferink, C. and Reiners, J.J., Jr. (2001) Regulation of Cyp 1a1 induction by dioxin as a function of cell cycle phase. J Pharmacol Exp Ther 299, 718-28.

[7] Scholler, A., Hong, N.J., Bischer, P. and Reiners, J.J., Jr. (1994) Short and long term effects of cytoskeleton-disrupting drugs on cytochrome P450 Cypla-1 induction in murine hepatoma 1c1c7 cells: suppression by the microtubule inhibitor nocodazole. Mol Pharmacol 45, 944-54.

[8] Dvorak, Z., Vrzal, R., Ulrichova, J., Pascussi, J.M., Maurel, P. and Modriansky, M. (2006) Involvement of Cytoskeleton in AhR-Dependent CYP1A1 Expression. Curr Drug Metab 7, 301-3.

[9] Dvorak, Z., Ulrichova, J. and Modriansky, M. (2005) Role of microtubules network in CYP genes expression. Curr Drug Metab 6, 545-52.

[10] Dvorak, Z., Modriansky, M., Ulrichova, J., Maurel, P., Vilarem, M.J. and Pascussi, J.M. (2005) Disruption of microtubules leads to glu cocorticoid receptor degradation in HeLa cell line. Cell Signal 17, 187-96.

[11] Dvorak, Z., Modriansky, M., Ulrichova, J. and Maurel, P. (2004) Speculations on the role of the microtubule network in glucocorticoid receptor signaling. Cell Biol Toxicol 20, 333-43.

[12] Abel, G.A., Wochnik, G.M., Ruegg, J., Rouyer, A., Holsboer, F. and Rein, T. (2002) Activity of the GR in G2 and mitosis. Mol Endocrinol 16, 1352-66.

[13] Cidlowski, J.A. and Cidlowski, N.B. (1982) Glucocorticoid receptors and the cell cycle: evidence that the accumulation of glucocorticoid receptors during the $\mathrm{S}$ phase of the cell cycle is dependent on ribonucleic acid and protein syn thesis. Endocrinology 110, 1653-62.

[14] Cidlowski, J.A. and Michaels, G.A. (1977) Alteration in glucocorticoid binding site number during the cell cycle in HeLa cells. Nature 266, 643-5.

[15] Distelhorst, C.W., Benutto, B.M. and Bergamini, R.A. (1984) Effect of cell cycle position on dexamethasone binding by mouse and human lymphoid cell lines: correlation between an increase in dexamethasone binding during $\mathrm{S}$ phase and dexamethasone sensitivity. Blood 63, 105-13.

[16] Hsu, S.C. and DeFranco, D.B. (1995) Selectivity of cell cycle regulation of glucocorticoid receptor function. J Biol Chem 270, 3359-64.

[17] Hsu, S.C., Qi, M. and DeFranco, D.B. (1992) Cell cycle regulation of glucocorticoid receptor function. Embo J 11, 3457-68. 
Dvořák et al.; Regulation of RAR receptors in rat hepatocytes.

[18] Hu, J.M., Bodwell, J.E. and Munck, A. (1994) Cell cycle-depend ent glucocorticoid receptor phosphorylation and activity. Mol Endocrinol 8, 1709-13.

[19] Dvorak, Z., Maurel, P., Ulrichova, J. and Modriansky, M. (2004) Microtubule disarray in primary cultures of human hepatocytes inhibits transcriptional activity of the glucocorticoid receptor via activation of c-jun N-terminal kinase. Biomed Pap Med Fac Univ Palacky Olomouc Czech Repub 148, 135-9.

[20] Brtko, J. and Thalhamer, J. (2003) Renaissance of the biologically active vitamin A derivatives: established and novel directed therapies for cancer and chemoprevention. Curr Pharm Des 9, 2067-77.

[21] Zanardi, S., Serrano, D., Argu sti, A., Barile, M., Puntoni, M. and Decensi, A. (2006) Clinical trials with retinoids for breast cancer chemoprevention. Endocr Relat Cancer 13, 51-68.

[22] Vivat-Hannah, V., You, D., Rizzo, C., Daris, J.P., Lapointe, P., Zusi, F.C., Marinier, A., Lorenzi, M.V. and Gottardis, M.M. (2001) Synergistic cytotoxicity exhibited by combination treatment of selective retinoid ligands with taxol(Paclitaxel). Cancer Res 61, 8703-11.

[23] Andela, V.B. and Rosier, R.N. (2004) The proteosome inhibitor MG132 attenuates retinoic acid receptor trans-activation and enhances trans-repression of nuclear factor kappaB. Potential relevance to chemo-preventive in terventions with retinoids. Mol Cancer 3, 8 .

[24] Boudjelal, M., Voorhees, J.J. and Fisher, G.J. (2002) Retinoid signaling is attenuated by proteaso me-mediated degradation of retinoid receptors in human keratinocyte HaCaT cells. Exp Cell Res 274, 130-7.

[25] Christine Pratt, M.A., Niu, M. and White, D. (2003) Differential regulation of protein expression, growth and apoptosis by natural and synthetic retinoids. J Cell Biochem 90, 692-708.

[26] Gianni, M., Bauer, A., Garattini, E., Chambon, P. and Rochette-Egly, C. (2002) Phosphorylation by $\mathrm{p} 38 \mathrm{MAPK}$ and recruitment of SUG- 1 are required for RA-induced RAR gamma degradation and transactivation. Embo J 21, 3760-9.

[27] Tanaka, T., Rodriguez de la Concepcion, M.L. and De Luca, L.M. (2001) Involvement of all-tran s-retinoic acid in the breakdown of retinoic acid receptors alpha and gamma through proteasomes in MCF-7 human breast cancer cells. Biochem Pharmacol 61, 1347-55.

[28] Moldeus, P., Hogberg, J. and Orrenius, S. (1978) Isolation and use of liver cells. Me thods Enzymol 52, 60-71.

[29] Ohata, M., Yamauchi, M., Takeda, K., Toda, G., Kamimura, S., Motomura, K., Xiong, S. and Tsukamoto, H. (2000) RAR and RXR expression by Kupffer cells. Exp Mol Pathol 68, 13-20.

[30] Kimura, Y., Suzuki, T., Kaneko, C., Darnel, A.D., Moriya, T., Suzuki, S., Handa, M., Ebina, M., Nukiwa, T. and Sasano, H. (2002) Retinoid receptors in the developing human lung. Clin Sci (Lond) 103, 613-21.

[31] Laemmli, U.K. (1970) Cleavage of structural proteins during the assembly of the head of bacteriophage T4. Nature 227, 680-5.

[32] Towbin, H., Staehelin, T. and Gordon, J. (1979) Electrophoretic transfer of proteins from polyacrylamide gels to nitrocellulose sheets: procedure and some applications. Proc Natl Acad Sci US A 76, 4350-4.

[33] Piacentini, M., Ceru, M.P., Dini, L., Di Rao, M., Piredda, L., Thomazy, V., Davies, P.J. and Fesus, L. (1992) In vivo and in vitro induction of 'tissue' transglutaminase in rat hepato cytes by retinoic acid. Biochim Biophys Acta 1135, 171-9. 
Dvořák et al.; Regulation of RAR receptors in rat hepatocytes.

[34] Pallet, V., Azais-Braesco, V., Enderlin, V., Grolier, P., Noel-Suberville, C., Garcin, H. and Higueret, P. (1997) Aging decreases retinoic acid and triiodothyronine nuclear expression in rat liver: exogenous retinol and retinoic acid differentially modulate this decreased expression. Mech Ageing Dev 99, 123-36.

[35] Dvorcakova, M., Macejova, D., Blazickova, S., Pallet, V., Higueret, P., Vasson, M.P., Walrad, S., Rock, E., Brtko, J. (2001) Transglutaminases: Protein cross-linking enzymes. In: Structure and stability of biomacromolecules (Atalik, M., ed.), pp. 33-34, SAS Kosice.

[36] Geisen, C., Denk, C., Gremm, B., Baust, C., Karger, A., Bollag, W. and Schwarz, E. (1997) High-level expression of the retinoic acid receptor beta gene in normal cells of the uterine cervix is regulated by the retinoic acid receptor alpha and is abnormally down-regulated in cervical carcinoma cells. Cancer Res 57, 1460-7.

[37] Pascussi, J.M., Drocourt, L., Fabre, J.M., Maurel, P. and Vilarem, M.J. (2000) Dexamethasone induces pregnane $\mathrm{X}$ receptor and retinoid $\mathrm{X}$ receptor-alpha expression in human hepatocytes: synergistic increase of CYP3A4 induction by pregnane $\mathrm{X}$ receptor activators. Mol Pharmacol 58, 361-72.

[38] Steineger, H.H., Arntsen, B.M., Spydevold, O. and Sorensen, H.N. (1997) Retinoid X receptor (RXR alpha) gene expression is regulated by fatty acids and dexamethasone in hepatic cells. Biochimie 79, 107-10.

[39] Yamaguchi, S., Murata, Y., Nagaya, T., Hayashi, Y., Ohmori, S., Nimura, Y. and Seo, H. (1999) Glucocortico ids increase retinoid-X receptor alpha (RXRalpha) expression and enhance thyroid hormone action in primary cultured rat hepatocytes. $\mathrm{J}$ Mol

Endocrinol 22, 81-90. 


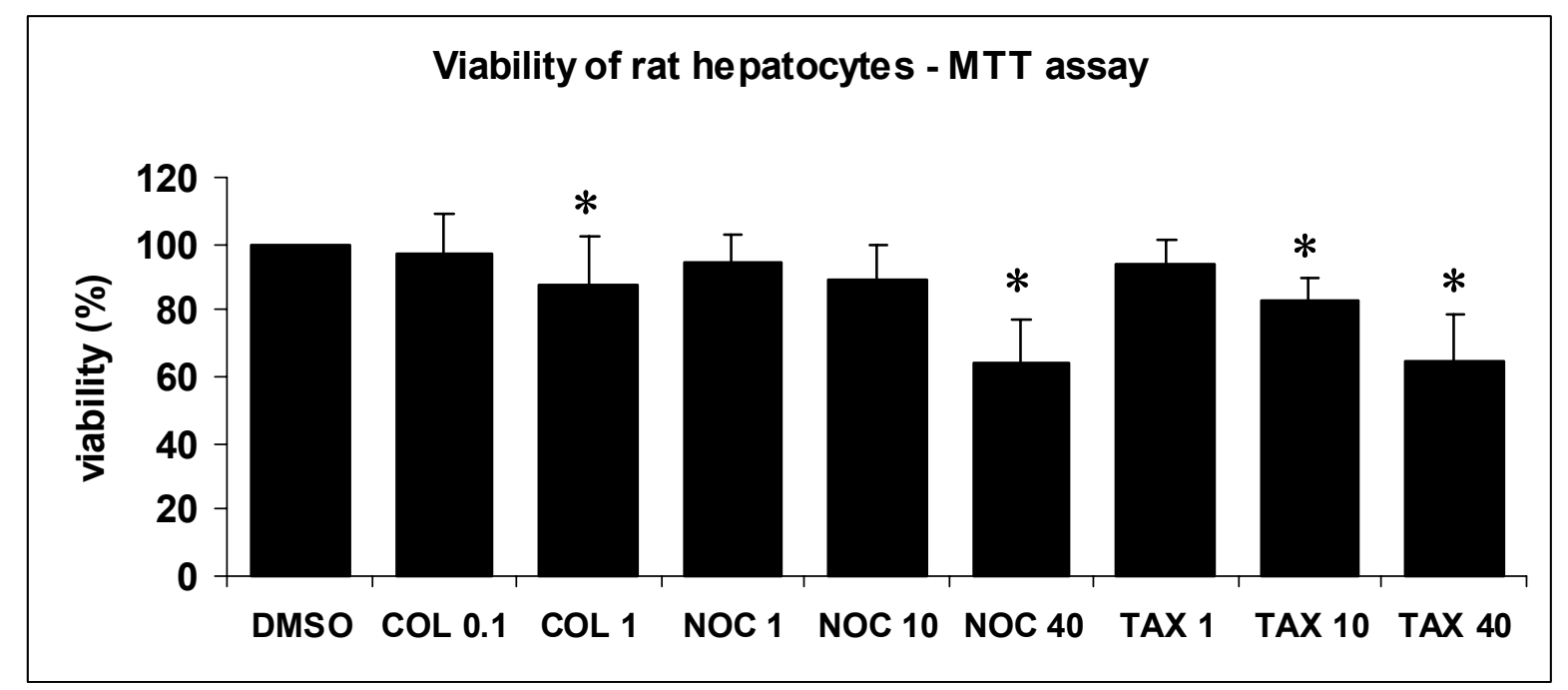

Figure 1 


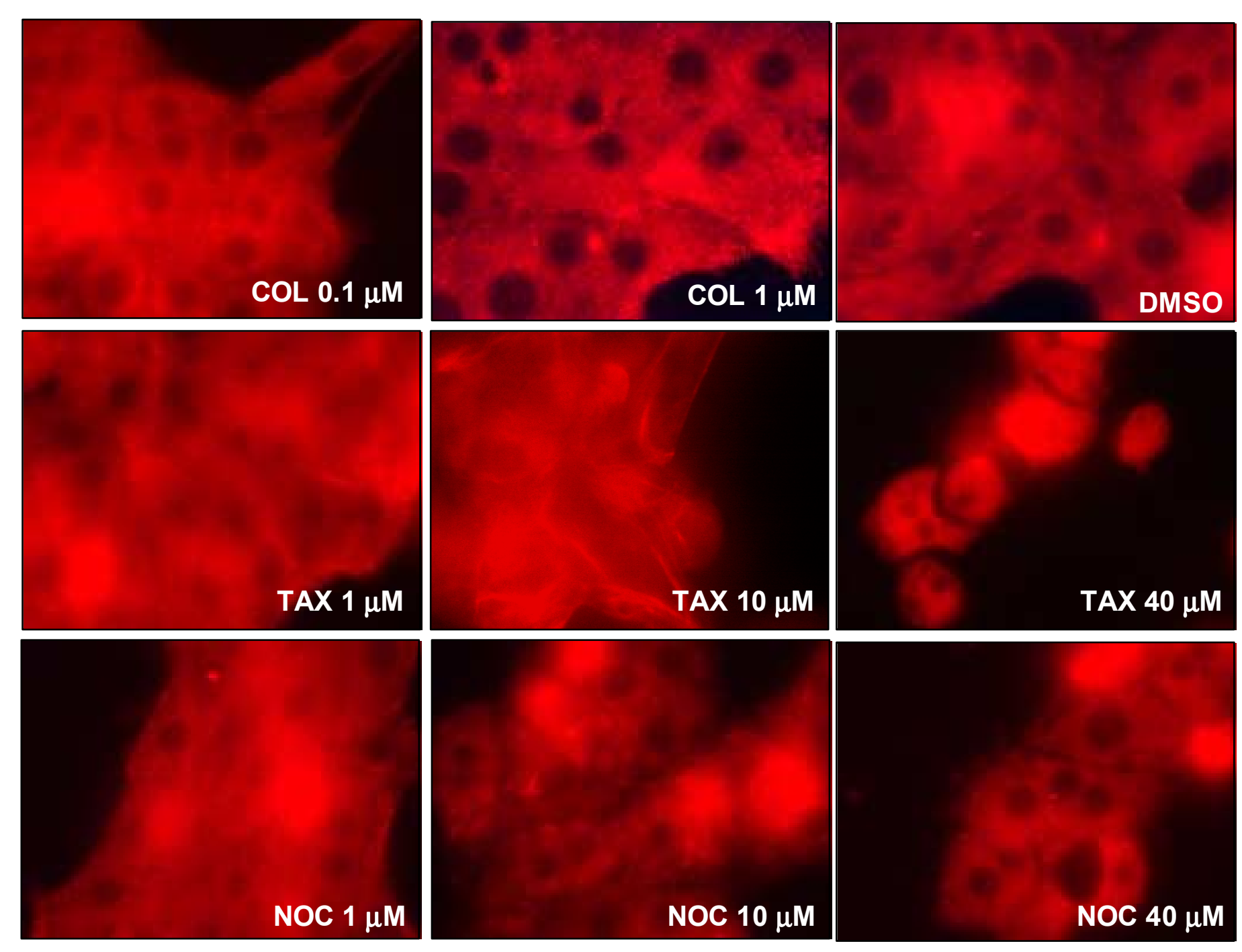

Figure 2 
Primary Rat Hepatocytes

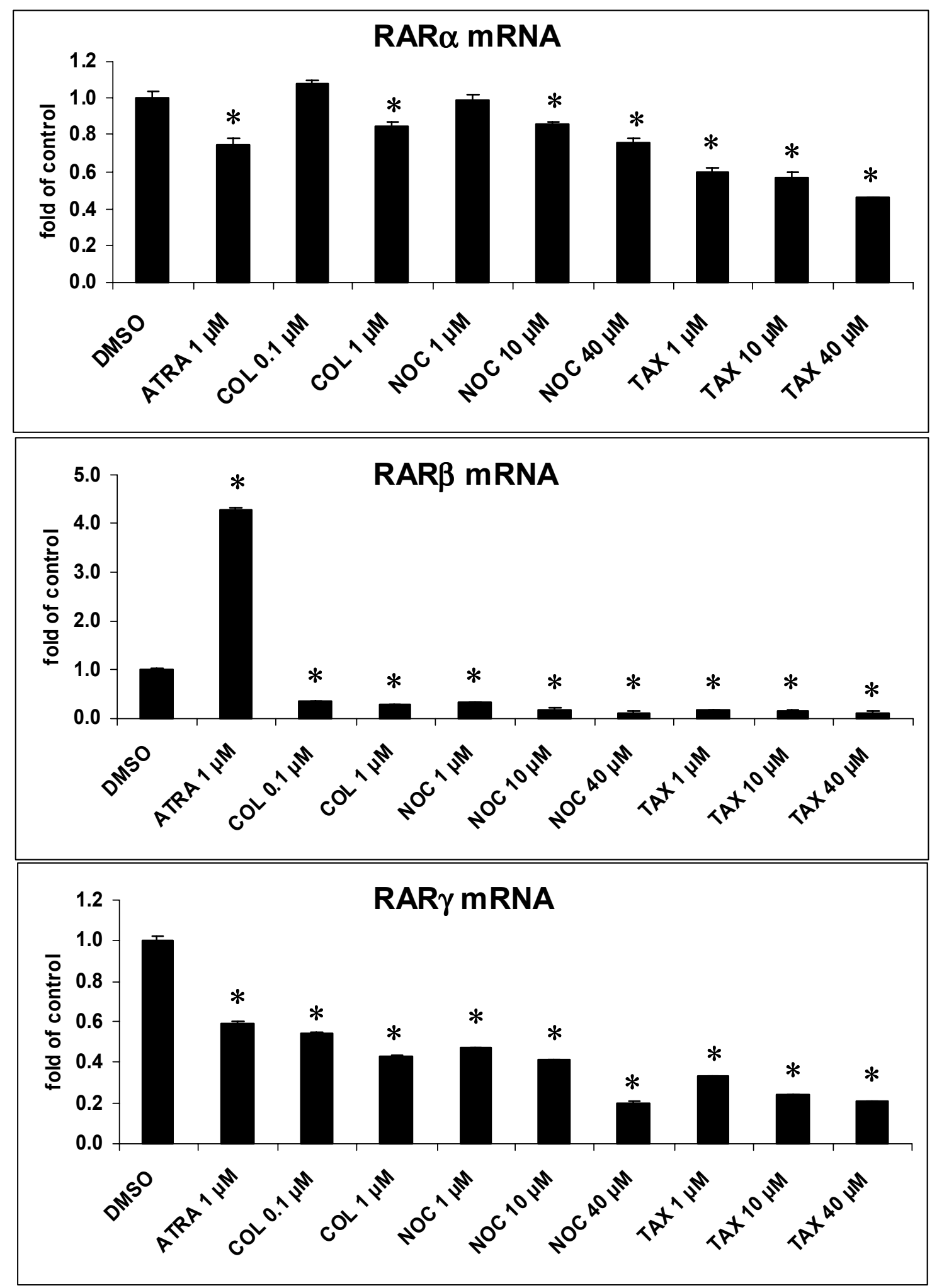

Figure 3a 


\section{HeLa cells}
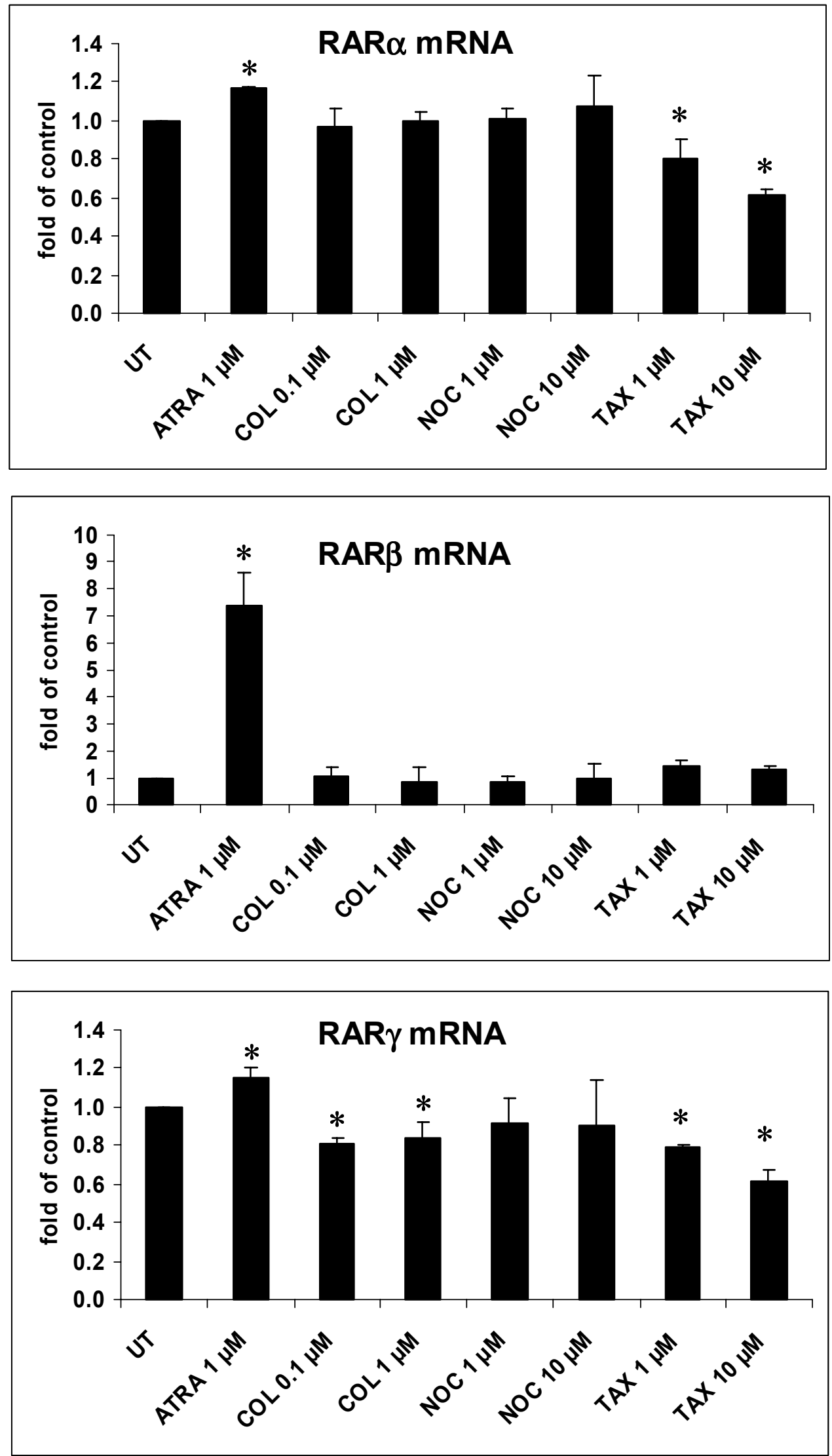

Figure $3 b$ 
A

Primary Rat Hepatocytes

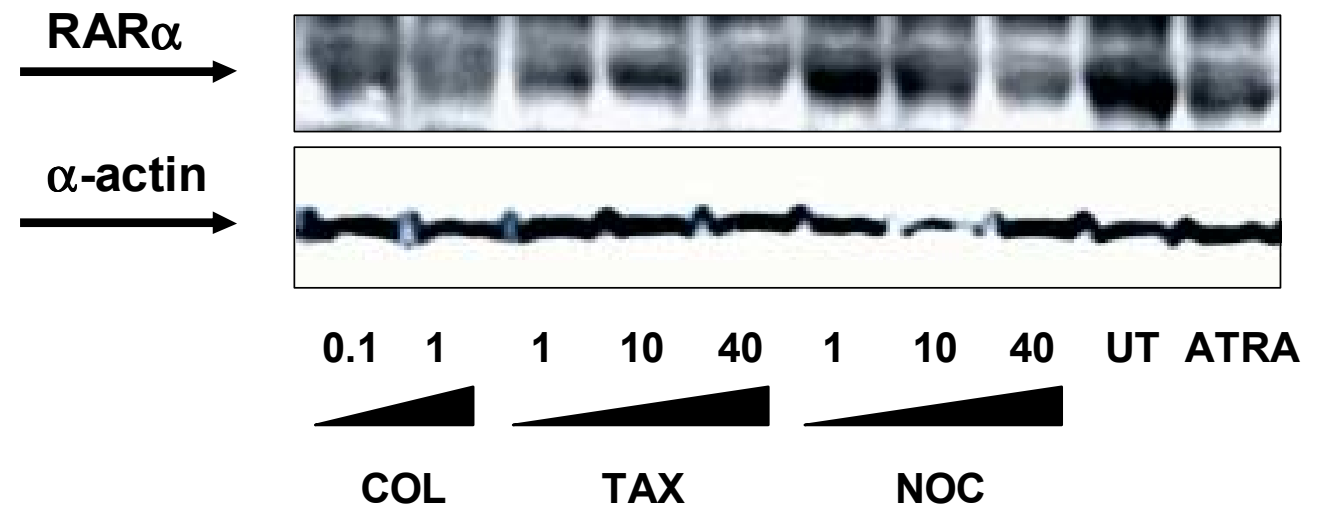

B

HeLa Cells

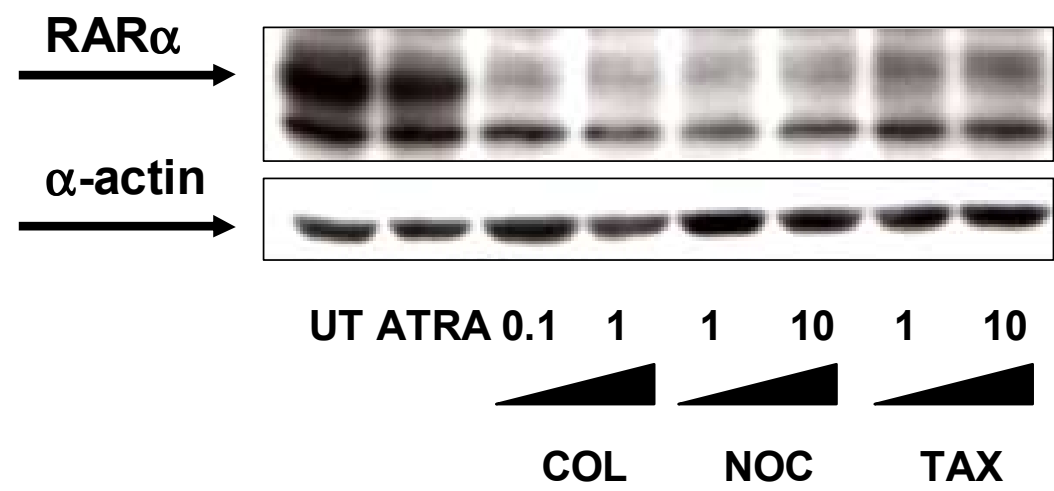

Figure 4 
Catalytic activity of trans-glutaminase

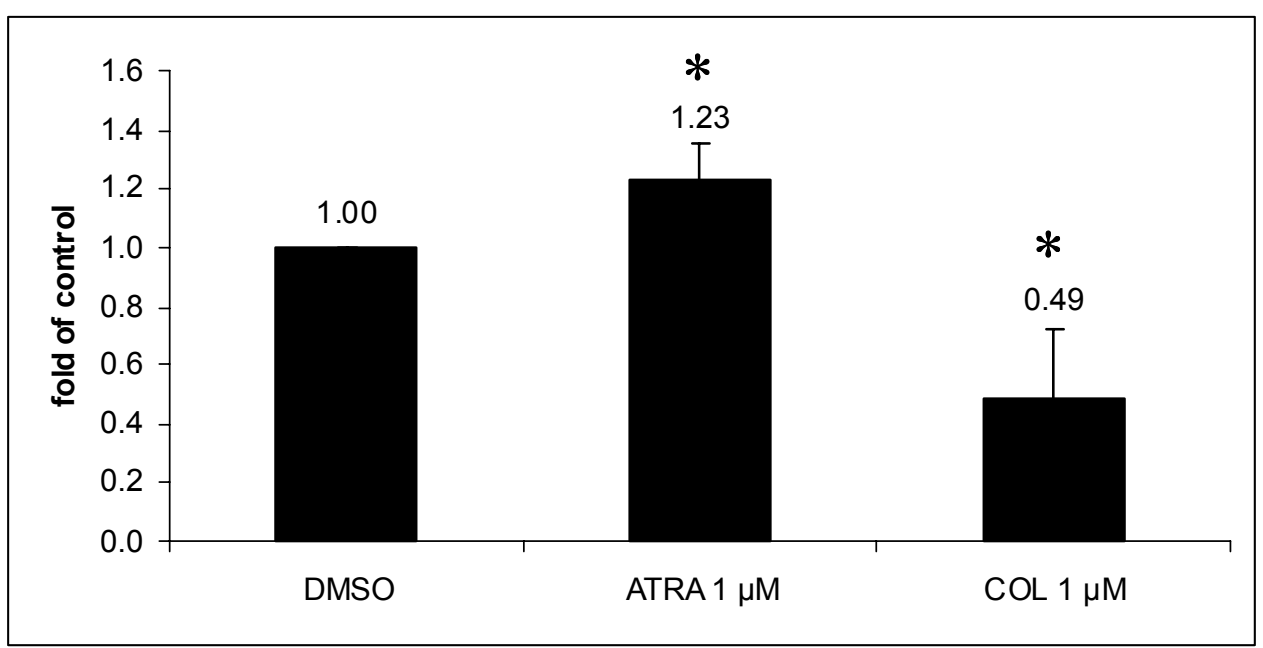

Figure 5 
A

Primary rat hepatocytes

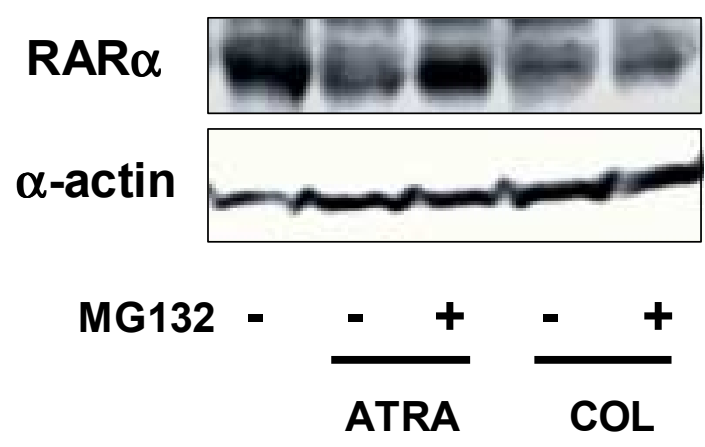

B Catalytic activity of trans-glutaminase

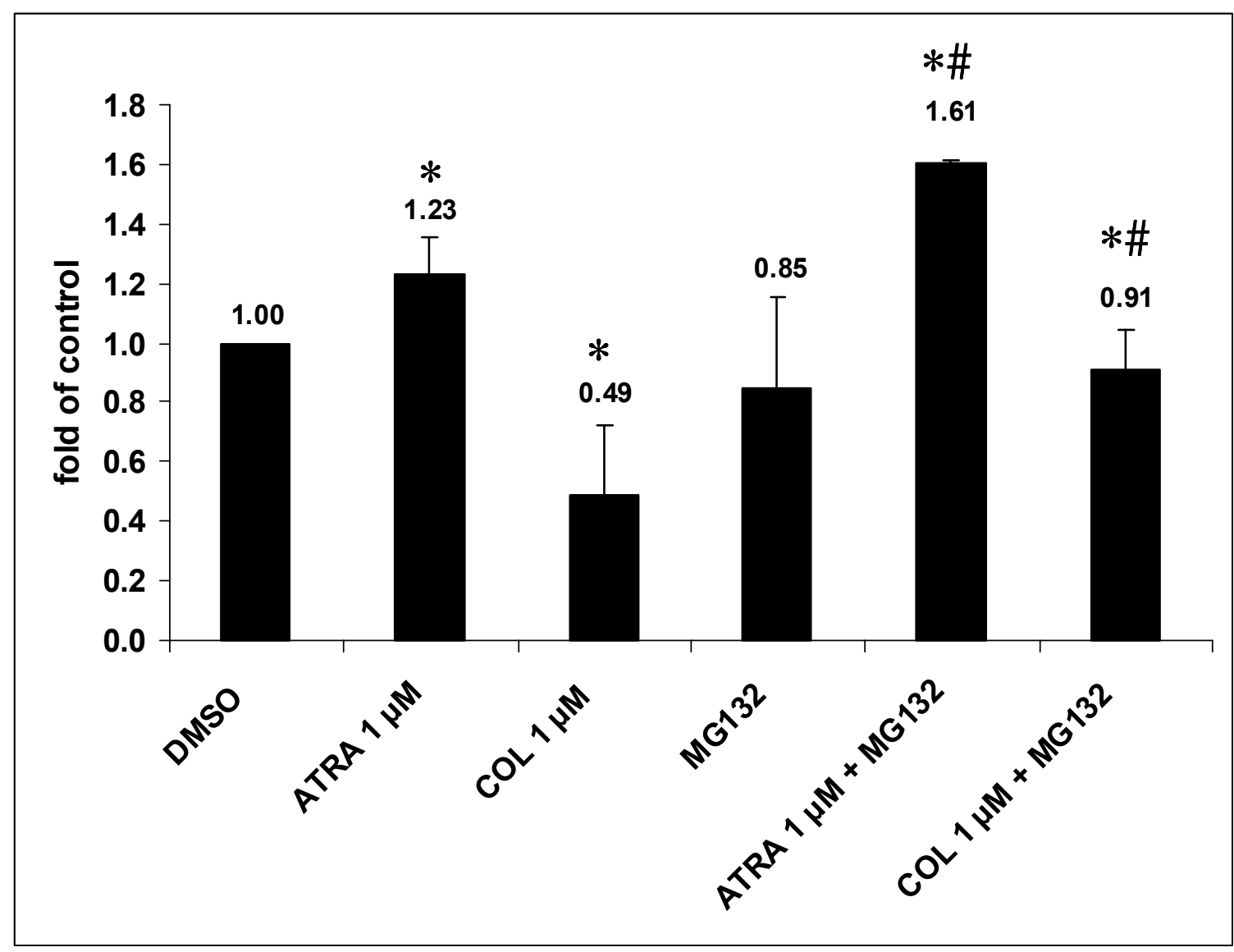

Figure 6 